\title{
Evaluation of productive and economic parameters of pigs in the final stage, with three feeding programs
}

\section{Evaluación de parámetros productivos y económicos de cerdos en la etapa de finalización, con tres programas de alimentación}

\author{
NOGUEZ-ESTRADA, Juan $\dagger^{*}$, AGUILAR-PRICILIANO, Tania, VARGAS-MONTER, Jorge and \\ RODRÍGUEZ-ORTEGA, Leodan Tadeo
}

Universidad Politécnica de Francisco I Madero

ID $1^{\text {st }}$ Author: Juan, Noguez-Estrada / ORC ID: 0000-0002-0493-8843. Research ID Thomson: X-4052-2018

ID $1^{\text {st }}$ Coauthor: Tania, Aguilar-Priciliano / ORC ID: 0000-0001-6446-6158

ID $2^{\text {nd }}$ Coauthor: Jorge, Vargas-Monter / ORC ID: 0000-0001-9845-2598

ID $3^{\text {rd }}$ Coauthor: Leodan Tadeo, Rodríguez-Ortega / ORC ID: 0000-0001-6561-4263

DOI: $10.35429 / J A N R E .2019 .4 .3 .25 .29$

Received March 14, 2019; Accepted June 30, 2019

\begin{abstract}
The objective was to evaluate the productive and economic parameters of pigs in the final stage with three commercial feeding programs. 240 pigs with homogeneous characteristics were used, assigning 40 females and 40 males completely random to the treatments. The animals were fed with 3 diets in flour containing different level of protein: T0 (16\%), T1 (16.42 $\%)$ and T2 (17.51). For the analysis of the information, a completely randomized design was used, the means were contrasted with the Tukey test. There were no significant differences $(\mathrm{P}>0.05)$ for the evaluated variables, with the highest consumption of dry matter $(\mathrm{CDM})$ recorded in the T1 (2,065), followed by T2 $(2,063)$ and T0 $(1,931 \mathrm{~kg}$.). The daily weight gain (DWG) was for T2 of 0.863 grs., $\mathrm{T} 1$ with $(0.858)$ and for T0 of 0.826 grs. With a food conversion (FC) for the proposal T0 of 2,562, T1 $(2,671)$ and T2 3,027 kg. The pigs fed with T1 recorded a cost of 16,869 / Kg. of live weight, followed by T2 with $\$ 14,556$ and obtaining more profitability with $\mathrm{T} 0$ when obtaining a cost of $\$ 13,248$. The productive behavior between treatments was similar, but the best profitability is obtained with the $\mathrm{T} 0$.
\end{abstract}

Pigs, Fattening, Behavior, Profitability

\begin{abstract}
Resumen
Objetivos El objetivo fue evaluar los parámetros productivos y económicos de cerdos en etapa de finalización bajo tres programas de alimentación comercial. Se utilizaron 240 cerdos con características homogéneas, asignando 40 hembras y 40 machos completamente al azar a los tratamientos. Los animales fueron alimentados con 3 dietas en harina conteniendo diferente nivele de proteína: T0 (16\%), T1 (16.42\%) y T2 (17.51). Para el análisis de la información, se utilizó un diseño completamente al azar, las medias se compararon con la prueba de Tukey. No existieron diferencias significativas $(\mathrm{P}>0.05)$ En las variables evaluadas, registrándose mayor consumo de materia seca (CMS) en el T1 (2.065), seguido de T2 (2.063) y T0 (1.931 kg.). La mayor Ganancia diaria de peso (GDP) fue para T2 de 0.863 grs., T1 con $(0.858)$ y para T0 de 0.826 grs. Con una conversión alimenticia (CA) para la propuesta T0 de 2.562, T1 (2.671) y T2 $3.027 \mathrm{~kg}$. Los cerdos alimentados con T1 registraron un costo de $16.869 / \mathrm{kg}$. de PV, seguido de T2 con \$14.556 y siendo más rentable con T0 al obtenerse un costo de $\$ 13.248$. En conclusión, el comportamiento productivo entre tratamientos fue similar, pero la mejor rentabilidad se obtuvo con el T0.
\end{abstract}

Cerdos, Engorda, Comportamiento, Rentabilidad

Citation: NOGUEZ-ESTRADA, Juan, AGUILAR-PRICILIANO, Tania, VARGAS-MONTER, Jorge and RODRÍGUEZ-ORTEGA, Leodan Tadeo. Evaluation of productive and economic parameters of pigs in the final stage, with three feeding programs. Journal-Agrarian and Natural Resource Economics. 2019. 3-4: 25-29

$\dagger$ Researcher contributing as first author. 


\section{Introduction}

In volume, pork represents a fifth of the total meat production in Mexico. In recent years, the industry has registered an average annual growth of $2.1 \%$. However, demand has shown a faster growth, causing a significant increase in imports, representing around $45 \%$ of apparent consumption. The United States is the main exporter to Mexico; Most of the imported products are fresh, chilled or frozen meats (OECD, 2019).

The evaluation of the cost of production and the indicators of the different production parameters are very important in pig farming. The parameters of pig production have generally improved in the last five years. This improvement did not directly imply a reduction in production costs due to high food prices (Rocadembosch, Amado, Bernaus, Font, \& Fraile, 2016).

For the pig industry, food accounts for about $70 \%$ of production costs. In recent years, food costs have increased by more than $226.6 \%$ since 2008. However, the demand for pork products is increasing, despite rising prices (Banson, Nketsia-Tabiri, Anno, \& Kofi Dagbui, 2014). The increase in feeding costs in recent years has generated challenging conditions for pig producers (Saddoris Clemons, Schneider, Feoli, Cook, \& Newton, 2011).

Conventional pig diets contain substantial amounts of cereal grains (for example, corn and wheat) and protein supplements such as soy flour to provide pigs with the energy and nutrients they need. However, trends in the demand and supply of these conventional foods require pig producers worldwide to seek low-cost alternatives (TWoyengo, Beltranena, \& Zijlstra, 2014).

The protein / energy ratio is important for the production yield and utilization of the food resources available to animals. In pig production, a low protein / energy ratio in the diet can be useful to reduce feeding costs and minimize the adverse effects of ammonia release in the environment (Yingying, et al., 2015).

To maximize profit opportunities, producers must develop feeding strategies that result in better yields on food and / or margin on food costs (Saddoris Clemons, Schneider, Feoli, Cook, \& Newton, 2011).
Food conversion represents the highest economic value in scenarios with high food prices (Rocadembosch, Amado, Bernaus, Font, \& Fraile, 2016). In the rations of traditional foods they present by stages deficits or excesses of nutrients according to the requirements of the animals; this causes more expensive productive activity and nutritional imbalances and shows that these portions are more expensive than food with the inclusion of unconventional raw materials (Estévez Alfayate, 2016).

In the feeding management of pigs in the final stage, food must be provided that meets the nutritional requirements depending on the level of production that is desired to be achieved, and the genetic potential of the animals, as well as reducing their cost when used in a manner efficient. Based on these elements, the present work aimed to evaluate the productive variables of pigs in the final stage, fed with three different diets in protein to determine the biological and economic optimum.

\section{Methodology to be developed}

Location. The project was carried out with pig producers in La Piedad Michoacán. It is located between the coordinates $20^{\circ} 21$ 'north latitude and between $102^{\circ} 02^{\prime}$ west longitude. Its territory extends to about 284.11 square kilometers and is at an average height of 1,680 meters above sea level.

\section{Installations}

6 pens of $40 \mathrm{~m} 2$ each were used with two feeders per pen and three drinking fountains with a firm floor and $1.5 \mathrm{~m}$ ponds, roofs of sheets and ventilation on both sides. The flow and availability of water in the pens was monitored every day, under the gram flow technique (in a bottle to determine how much water flows in a minute) expected parameter $2.5 \mathrm{~L} / \mathrm{min}$. With lighting-saving bulbs for the entire house.

\section{Treatments}

The farm was considered as an independent experiment due to its particular conditions, three treatments were evaluated:

T0: Food in presentation of flour with $16 \%$ protein for pigs in the final stage.

T1: Food in presentation of flour with $16.42 \%$ protein for pigs in the final stage.

NOGUEZ-ESTRADA, Juan, AGUILAR-PRICILIANO, Tania, VARGASMONTER, Jorge and RODRÍGUEZ-ORTEGA, Leodan Tadeo. Evaluation of productive and economic parameters of pigs in the final stage, with three feeding programs. Journal-Agrarian and Natural Resource Economics. 2019 
T2: Food in flour presentation with 17.51 protein for pigs in the final stage.

\section{Animals}

240 animals were used being 120 females and 120 castrated males, with homogeneous characteristics [age, live weight (PV), genetics, sanitary condition, etc.], of which they were randomly assigned and with the same number of males and females to the treatments.

\section{Weighing and stamping of animals}

The animals were identified at the beginning of the experiment, listing from 1 to 80 for each treatment. Weighing was carried out at the beginning and at the end of the experiment by introducing the animals into a mobile electronic scale type drawer, where the corresponding reading was carried out.

\section{Feeding}

Ad libitum food was provided twice a day, (9:00 am and 3:00 pm), always at the same time. The food was offered with the support of a table based on food consumption by stage (see Table $1)$.

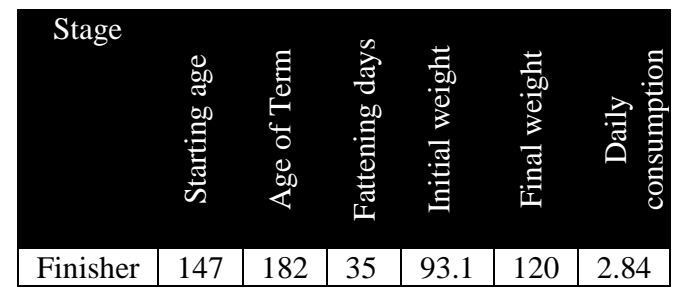

Table 1 Feed proposal for pigs in completion stage

Table 2 shows the nutritional composition of each food used in each of the treatments.

\begin{tabular}{|l|r|r|r|}
\hline \multicolumn{1}{|c|}{ NUTRIMENT } & \multicolumn{1}{c|}{ T1 } & \multicolumn{1}{c|}{ T2 } \\
\hline PC\% & 16 & 16.42 & 17.51 \\
\hline $\begin{array}{l}\text { METABOLIZABLE } \\
\text { ENERGY (kcal) }\end{array}$ & 3320 & 3300 & NE \\
\hline GREASE (\%) & & & \\
\hline FIBER\%) & 3.5 & 3.09 & 4.13 \\
\hline ASHES (\%) & 4 & 3.96 & 1.97 \\
\hline P TOTAL (\%) & 0.45 & 0.66 & 0.409 \\
\hline Total Ca (\%) & 0.53 & $\mathrm{NE}$ & 0.477 \\
\hline
\end{tabular}

Table 2 Nutritional composition of the diets of each of the treatments

\section{Duration of fattening}

The experimental period was 35 days in order to reach $120 \mathrm{~kg}$ of PV per animal.

\section{Variables to measure}

\section{Daily food consumption (CDA)}

The amount of food offered for each of the treatments was weighed before filling the feeders, and the rejection was weighed the next day.

$\mathrm{CDA}=$ Food offered-food rejected

\section{Daily Weight Gain (GDP)}

The daily weight gain was calculated considering the final weight (Pvf) minus the initial weight (Pvi) divided between the days of fattening.

GDP $=$ Pvf-Pvi) / fattening days

\section{Food conversion}

It was estimated by dividing the daily food consumption by the daily weight gain.

$\mathrm{CA}=$ Daily food consumption / GDP

\section{Cost per kg of PV produced (\$ / Kg of PV)}

The cost per kilogram of live weight produced was calculated by multiplying the food conversion by the price of each food.

\section{Statistic analysis}

A completely randomized design was carried out, being the experimental unit of 80 animals.

$$
Y_{i j}=\mu+T i+\varepsilon i j
$$

The data were analyzed by means of an analysis of variance and comparison of means with Tukey test $(\alpha \leq 0.05)$ using the statistical software SAS version 9.0. 


\section{Results}

The analysis of the evaluated variables, in the three protein levels proposed, showed that there were no significant differences $(\mathrm{P}>0.05)$, in any of the variables evaluated in pigs in the period of completion.

\section{Cost per kg of PV produced (\$ / kg of PV)}

The productive and economic results expressed by the pigs in the final stage using three levels of protein in the diet (T0, T1, and T2), are shown in Table 3.

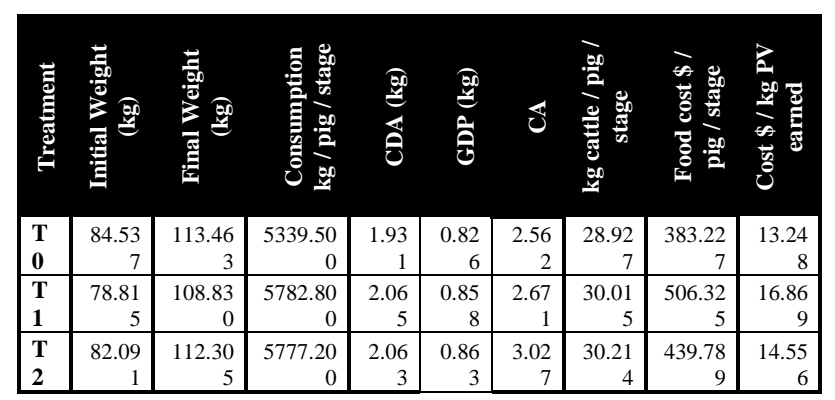

Table 3. productive and economic indicators of pig behavior in the final stage with three feeding proposals

When performing the analysis of the productive behavior (Table 3), it was observed that the pigs that consumed T2 feed $(30,214 \mathrm{~kg})$, recorded more kilograms gained. No differences were observed in the animals of $\mathrm{T} 1$ and $\mathrm{T} 0$ $(30,015$ vs $28,927 \mathrm{~kg})$, however, the lowest recorded gain was obtained from the animals of T0 (Table 3). When analyzing the cost generated by pig in completion, the animals of the T0 recorded the lowest cost: 383,227 pesos. While, the animals of $\mathrm{T} 2$ generated an investment cost of $\$ 439,789$, on the other hand, pigs of T1 had the highest cost generated by investment with $\$$ 506,325 pesos per animal.

When analyzing the cost per kilogram of live weight gained, pigs fed $\mathrm{T} 1$ treatment recorded a cost of $16,869 / \mathrm{kg}$ of $\mathrm{PV}$, followed by T2 with $\$ 14,556$ and pigs fed with T0 treatment being more profitable when obtaining a cost of $\$ 13,248 / \mathrm{kg}$ of PV.

\section{Acknowledgment}

The authors express their gratitude to the pork producers of La Piedad Michoacán and to the Polytechnic University of Francisco I. Madero for the facilities provided for carrying out the work.

\section{Conclusions}

The completion stage is the most expensive period for food conversion, therefore, economic and efficient diets that impact profitability should be formulated. There were no differences in the productive response of pigs fed the three levels of protein. However, the best conversion and profitability are obtained by feeding pigs in completion with $16 \%$ crude protein.

\section{References}

Banson, K., Nketsia-Tabiri, J., Anno, K., \& Kofi Dagbui, E. (2014). Economic and Market Analysis of Swine Rearing and Pork Production in Ghana. Journal of Life Sciences, 8(8). Obtenido

file://C:/Users/LatitudeE6430/Downloads/Eco nomicandMarketAnalysisofSwineRearingandP orkProductioninGhana-2.pdf

Estévez Alfayate, J. (2016). Manejo alimentario en las etapas de preceba y ceba en una unidad integral de producción porcina. Rev. prod. anim, 12-19.

OECD. (2019). MARKET EXAMINATIONS IN MEXICO: CASE STUDY OF THE PORK MEAT MARKET (C) OECD 2019. Obtenido de https://www.oecd.org/daf/competition/marketexaminations-in-mexico-pork-meat-market.htm

Rocadembosch, J., Amado, J., Bernaus, J., Font, J., \& Fraile, L. (2016). Production parameters and pig production cost: temporal evolution 2010-2014. Porcine Health Management, 2(11). doi:DOI 10.1186/s40813-016-0027-0

Saddoris Clemons, K., Schneider, J., Feoli, C., Cook, D., \& Newton, B. (2011). Cost-Effective Feeding Strategies for Grow-Finish Pigs. Advances in Pork Production, 22, 187. Obtenido de

https://pdfs.semanticscholar.org/f0f7/dff151d86 73f24e1812fb43127be9b2db556.pdf

TWoyengo, T., Beltranena, E., \& Zijlstra, R. (2014). NONRUMINANT NUTRITION SYMPOSIUM: Controlling feed cost by including alternative ingredients into pig diets: A review. J. Anim. Sci., 92(4), 1293-1305. doi:10.2527/jas2013-7169 
Yingying, L., Kong, X., Jiang, G., Tan, B., Deng, J., Yang, X., . . . Yin, Y. (2015). Effects of dietary protein/energy ratio on growth performance, carcass trait, meat quality, and plasma metabolites in pigs of different genotypes. JOURNAL OF ANIMAL SCIENCE AND BIOTECHNOLOGY, 6(26). doi:10.1186/s40104-015-0036-X 